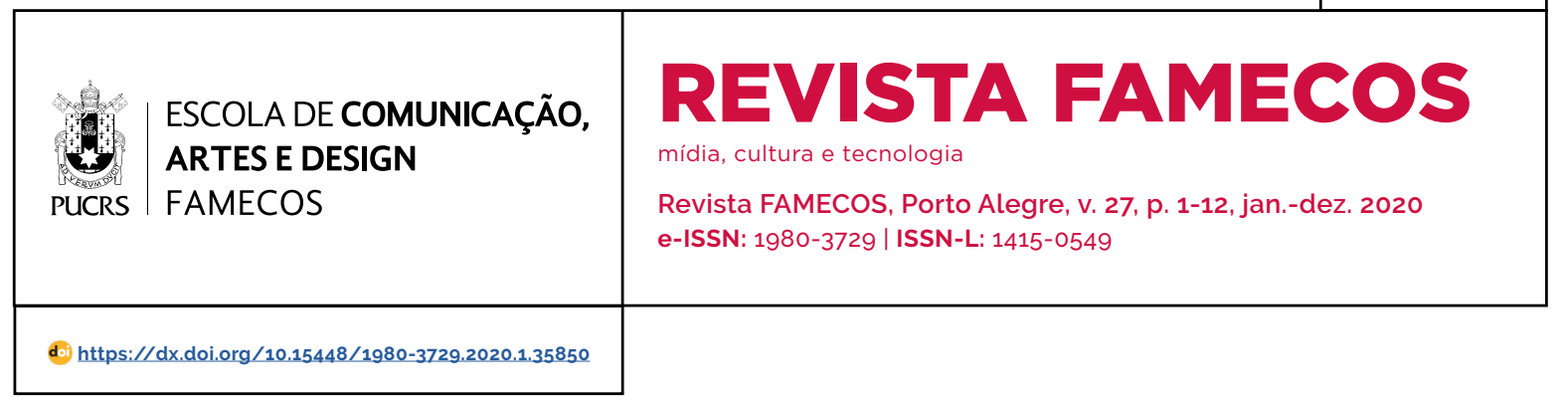

JORNALISMO

\title{
Mobile phones in young people everyday life: case study with Portuguese and Brazilian students ${ }^{1}$
}

\author{
Telefones celulares no cotidiano dos jovens: um estudo de caso com estudantes \\ portugueses e brasileiros
}

Teléfonos móviles en la vida cotidiana de los jóvenes: estudio de caso con estudiantes portugueses y brasileños

\author{
João Canavilhas ${ }^{2}$ \\ orcid.org/0000-0002-2394-5264 \\ jc@ubi.pt
}

\section{Eduardo Pellanda 3}

orcid.org/0000-0002-8296-9282

eduardo.pellanda@pucrs.br

\section{Valeriano Piñeiro-Naval ${ }^{2}$ \\ orcid.org/0000-0001-9521-3364 vale.naval@labcom.ubi}

\section{Ana Cecilia B. Nunes 3 \\ orcid.org/0000-0002-4018-2676 ana.nunes@pucrs.br}

Recebido em: 30 set. 2019 Aprovado em: 29 out. 2019 Publicado em: 28 mai. 2020

\section{c) (i)}

Artigo está licenciado sob forma de uma licença Creative Commons Atribuição 4.0 Internacional.

\begin{abstract}
Mobile phones have become commonplace everyday objects in almost all societies regardless of their development stage. The presence of these devices has become a constant on any latitude, as shown by the penetration rate figures for 2018: $65.9 \%$. These numbers, already surprising on their own, reach even higher values among young people. Thus, this paper studies the use of mobile phones, in particular smartphones, by young Portuguese and Brazilian university students. For this purpose, an app that registered all the uses made by the youngsters in their mobile devices, was employed. This methodology allows data collection in a daily context without the participants feeling controlled. A total of 317,938 interactions, registered in the participants devices, shows that the main use given to these devices is as a platform for access to social networks, followed by the sending of messages and the variable "second uses" of the device (watch, calendar, camera, calendar and calculator). Although this is a study in progress, at this stage it is safe to state that the data confirm previous studies (FORTUNATI; TAIPALE, 2014) in which smartphones assert themselves as a verbal written communication platform in opposition to their genesis based on orality. Keywords: Media studies. Mobile technology. Communication studies.
\end{abstract}

Resumo: Os telefones celulares se tornaram objetos comuns do dia-a-dia em quase todas as sociedades, independentemente do estágio de desenvolvimento. A presença desses dispositivos tornou-se constante em qualquer latitude, como mostra o índice de penetração em 2018: 65,9\%. Esses números, já surpreendentes por si só, atingem valores ainda mais altos entre os jovens. Assim, este artigo estuda o uso de telefones celulares, em particular smartphones, por jovens estudantes universitários portugueses e brasileiros. Para isso, foi desenvolvido um aplicativo que registrava todos os usos feitos pelos jovens em seus dispositivos móveis. Essa metodologia permite a coleta de dados em um contexto diário sem que os participantes se sintam controlados. Um total de 317.938 interações, registradas nos dispositivos participantes, mostra que o principal uso dado a esses dispositivos é como plataforma de acesso às redes sociais, seguido pelo envio de mensagens e pela variável "segundos usos" do dispositivo (observe, calendário, câmera, calendário e calculadora). Embora este seja um estudo em andamento, é possivel afirmar que os dados confirmam estudos anteriores (FORTUNATI; TAIPALE, 2014) em que os smartphones se afirmam como uma plataforma de comunicação verbal escrita em oposição à sua gênese baseada na oralidade.

Palavras-chave: Estudos de Mídia. Tecnologia móvel. Estudos de comunicação.

Resumen: Los teléfonos móviles se han convertido en objetos cotidianos comunes en casi todas las sociedades, independientemente de su etapa de

\footnotetext{
This work was supported by CAPES/PDSE under Grant [number 88881.190396/2018-01] received by Ana Cecilia Bisso Nunes and by Portugal's Foundation for Science and Technology (SFRH/BPD/122402/2016) received by Valeriano Piñeiro-Naval. No potential conflict of interest was reported by the authors. An abstract of this research was accepted and presented at ECREA 7th European Communication Conference (ECC), in Lugano (Switzerland), but a license to publish the work was not granted to the conference organizers. University of Beira Interior (UBI), Covilhã, Portugal.

Pontifical Catholic University of Rio Grande do Sul (PUCRS), Porto Alegre, RS, Brasil.
} 
desarrollo. La presencia de estos dispositivos se ha convertido en una constante en cualquier latitud, como lo muestran las cifras de tasa de penetración para 2018: $65.9 \%$. Estas cifras, que ya son sorprendentes por si mismas, alcanzan valores aún más altos entre los jóvenes. Así, este documento estudia el uso de teléfonos móviles, en particular teléfonos inteligentes, por jóvenes universitarios portugueses y brasileños. Para este propósito, se empleó una aplicación que registraba todos los usos realizados por los jóvenes en sus dispositivos móviles. Esta metodología permite la recolección de datos en un contexto diario sin que los participantes se sientan controlados. Un total de 317,938 interacciones, registradas en los dispositivos de los participantes, muestran que el uso principal que se les da a estos dispositivos es como una plataforma para acceder a las redes sociales, seguido por el envio de mensajes y las variables "segundos usos" del dispositivo (ver, calendario, cámara, calendario y calculadora). Aunque este es un estudio en progreso, en esta etapa es seguro afirmar que los datos confirman estudios previos (FORTUNATI; TAIPALE, 2014) en los que los teléfonos inteligentes se afirman como una plataforma de comunicación verbal escrita en oposición a su génesis basada en la oralidad.

Palabras clave: Periodismo. Tecnología móvil. Estudios de comunicacion.

\section{Introduction}

Throughout history, new technologies have always been a motor for social development, however, never before were they within the reach of the majority. Either due to economic reasons (high costs) or because their purpose was the collective usufruct, never has a new technology played such a central role in society as the one currently held by mobile technologies associated with mobile phones.

The social dynamic that allows a constant adaptation between technologies and societies (LASEN, 2004) has been particularly enthusiastic in the case of mobile phones, with these devices shaping society and vice versa. Technological developments cause changes in users' attitudes, which in turn generate new social and cultural phenomena that also require technologies to evolve in order to respond to consumer demands (AOKI; DOWNES, 2003). This paper studies how a specific group - young Portuguese and Brazilian university students - uses their smartphone. For this purpose, an application was developed and installed in the student's devices during a month that allowed monitoring what type of use they gave to their mobile phone. During the period under analysis, 317,938 interactions were registered, of which the 64,881 related to the use of mobile applications in smartphones were studied in the realm of this research.

Resorting to an application to monitor the use of the devices permitted the understanding of the role of smartphones from a context of uncontrolled use. Thus, this methodology differs from the classical methodologies used for this type of research (such as interviews, research and controlled experiments) or daily use (WEI, 2007), proposing an approach to data in a daily context.

Data analysis revealed that these devices are largely used as platforms for/to access to social networks, overriding significantly their secondary use - sending messages and the device's "second uses" variable (clock, calendar, camera, calendar and calculator). Other procedures displayed in the study are navigation (4th), voice service which was the genesis of the mobile phone (5th), video consumption (6th), music consumption (7th), e-mail (8th) and access to news (9th). In addition, it is anticipated that the emergence of more affordances and the response to new user's needs will fuel the innovation process that will reinforce the role of mobile phones in society.

\section{The mobile phone in present day society}

Today' ubiquity of communication allows us to be near and far at the same time (TURKLE, 2017). Virtuality is an omnipresent, interconnected and diversified system (CASTELLS; MAJER; GERHARDT, 2002) with information virtualization permeating the deterritorialisation of LÉVY (1996). An investigation by Pew Research (RAINIE; ZICKUHR, 2015, n/p) states that "'always on' mobile connectivity possess new challenges for users about when to be present with those nearby or engaged with other on their screens"

Mobile devices have altered the way we consume, process and relate to information and others, with its originality it allowed this to happen simultaneously in emerging and developed countries albeit in different ways. Aker and Mbiti (2010: 209) illustrate this reality with an example: "while the telecommunications industry in the United States, Canada and Europe invested in 
landlines before moving to mobile phone networks, the mobile phone has effectively skipped the landline in Africa". That is, in developing countries there was no slowdown in cell phone broadcasting due to the lack of fixed lines, on the contrary, a jump occurred directly to mobile phones.

The reasons for the success of mobile phones rely on features inherited from the landline phone, which Keep friends and family connected (Wellman \& Tindall, 1993) and reduce isolation and anxiety (Fisher, 1992), plus those that are characteristic of these devices, such as Feeling of better personal safety (DIMMICK; SIKAND; PATTERSON, 1994), Mobility, Usability and Multimediality (AGUADO; MARTÍNEZ, 2008).

In the Brazilian context, the country surpassed the benchmark of more than one mobile phone per inhabitant in 2010, according to the National Telecommunications Agency (Anatel) data. By March 2018 there were more than 235 million mobile lines operating with a density of 113.54 lines per 100 inhabitants (ANATEL, 2018). According to the Brazilian Media Survey, despite the fact that the main point of access to the Internet (timewise) is still the computer, the percentage of users that accesses the Internet mainly through mobile phones is higher among those who earn less (SECOM, 2014). Among young people under the age of $25,65 \%$ says they access the internet every day (SECOM, 2015). Considering the average low income of the country, this numbers indicate the importance of these devices in a broad spectrum of social classes.

In the Portuguese context, a survey of the ERC (2015) revealed that seven out of ten Portuguese use the internet, regardless of the device. Among the devices most used the computer leads (96\%), followed by the smartphone (51\%) and the tablet (19\%). Considering consumption among youngsters, $92.5 \%$ of students aged 19-22 years use the internet every day while the range between 23-26 years or over 26 years old have a daily usage percentage of around $80 \%$.

The ubiquity of the information, connectivity, and functionality in smartphones offers a range of features that were once scattered among other devices, such as calculators, watch, notepad and, of course, internet access. The omnipresence of these devices in daily life and their centrality as a medium means that there is an increasing dependence on smartphones today (Ahn \& Jung, 2016). Both digital immigrants and digital natives recognize this reality but do nothing to change it, which expresses a lot about the importance of mobile phones in everyday life. According to Ahn and Jung (2016), for digital natives, the dependence of the device has as its main causes (in order of importance) portability, games and convenience / usefulness of the device, the main symptoms (for them) being abdication of face-to-face interaction, interruption of study/ work, loss of time, and physical symptoms. This self-criticism of the digital natives in relation to the excessive use of the cell phone conveys a lot about the singular and central role of these devices in the daily life of young people.

For Turkle (2017), these young people represent the focus of this change in a generation where young people teach their elders to navigate this informational environment. If we use 1995 as standpoint, i.e. the beginning of the commercial expansion of the Internet, and the year 2007, i.e. iPhone launch and expansion of network mobility, we have two generations of "digital natives" creating two gaps between people living in the year 2018. Due to the features already mentioned in this paper, the current environment of information ubiquity is considered not only as an evolutionary stage of the Internet but also as an invention of new interactions that change the perception of the network and may even make it invisible.

After more than ten years of this last shift, a more mature use of this technology can now be assessed and thus the understanding of how it influences different strata of society. It is no longer talked of early adopters or users still infected by the fetish of new technology, but of a technology so appropriate by society that it has become an essential element to its normal functioning. Despite this, the younger continue to maintain a special interest in the emerging technological innovations, thus being an important group to evaluate the tendencies of future. 


\section{Young people and mobile phones}

The ubiquity of communication based on the massification of mobile devices has led society to a context of divided attention, multitasking and the transformation of social interactions. Mobile phones are the fastest-growing technology in the history of communications: Android and iOS devices rate of adoption was 10 times faster than the one of personal computers in the 1980s, twice as fast as the popularization of commercial Internet in the 1990 s and three times faster than the recent adoption of social networks (FARAGO, 2012).

The worldwide spread of these devices in a short span of time is related to important changes in the communication and sociability of people of all age groups. However, it should be noted that today, more than 10 years after the launch of the iPhone, we live in a context in which the young people were born and/or grew up surrounded by these digital communication technologies. For Prensky (2001, p. 1), young people born with digital technologies (here also considering computers) can be called Digital Natives, as they are "native speakers" of the digital language of computers, video games and the Internet." The remaining users can be seen as Digital Immigrants, since they have come to live and use these technologies throughout their lives.

For the young university students of this study, usually aged between 17 and 26 years old in the Brazilian and Portuguese context, mobile phones have been part of their universe since the beginning of their school life. The relationship of this group with these devices is so strong that even new skills are required or even coveted. Turkle (2015, n / p) comments that some college students report that they are able to look someone in the eye while typing on their smartphones: "They say it's a skill they mastered in middle school when they wanted to text in class without getting caught. Now they use it when they want to be both with their friends and, as some put it, 'elsewhere'".

Regarding the use of smartphones by university students, a survey, based on questionnaires answered by 1,566 students ( $4 \%$ of the Institution's total students), conducted at Purdue University in the United States, showed a preference of the participants for apps in detriment of the use of the mobile browser (BOWEN; PISTILLI, 2012).

The authors also realized that as users become more advanced in the use of handsets, apps consumption tends to increase while browser consumption remains unchanged. Students reported that they use mobile applications mainly for games (1st place), time (2nd place), music (3rd place), geolocation (4th place), social networks (5th place), entertainment (6th place), news (7th place), education (8th place), sports (gth place), references (10th place) and shopping (11th place). It should be borne in mind that this is the usage referred to by the user, that is, what he/she says he/she does and not the measurement of his/hers actual use, as in the present investigation. Lastly, the research also points out that most students find apps faster $(68 \%)$ and easier to use $(70 \%)$ when compared to browser or browser access. Thus, it can be said that digital natives prefer apps, the focus of this study.

Smartphones seem to have taken a central place in contemporary society, becoming a privileged channel of communication with the world and amongst people. But they may also be replacing other classical utilities such as clocks and calculators, for example, further enhancing their role in the individuals' lives. This research seeks precisely to verify what young people do with their smartphones.

\section{Methodology}

The present study aims to understand how Portuguese and Brazilian university students use smartphones, taking as starting point the fact that these young people belong to an always-on generation (PELLANDA, 2005). The approach of the smartphone as central object of this research starts from methodological impasses and previous studies (PELLANDA ET AL., 2018) in which it was possible to understand the challenges of this type of analysis. Among them is the collection of information in a daily context, with a smaller sense of control and observation for the participants but respecting their privacy. 
Full understanding of the role of smartphones in the daily life of the audiences, especially in uncontrolled contexts, has been a point of discussion among researchers in the area. Wei (2007), in a literature review of research methods for mobile devices, emphasizes that the research strategies that have the smartphone as a central object can be divided into three categories: classical methodologies (interviews, research and controlled experiments), user's diaries made by the participants and, finally, the capture of data of the mobile phone in real time through automated tools.

In order to understand the behaviour of young Brazilians and Portuguese students in relation to smartphones and given the centrality of the use of applications to perform tasks in these devices, we selected the last method mentioned by the author. Unlike the strategy of obtaining screenshots, undertaken by Muise, Pan and Reeves (2017), we opted for storing data through our own application, validated in an earlier research (PELLANDA et al., 2018) and specially adapted to the needs of this study. The application developed has the characteristic of operating exclusively on Android operating systems, which, considering the scope of this operating system in the two countries, did not affect the sampling of the research. In Brazil, the Android operating system represented more than $84 \%$ of the market during the year 2017 and in Portugal, around $74 \%$ of the market this year (STATCOUNTER GLOBAL STATS, 2018a, 2018b) The iOS ecosystem, although it can add to the data, was not used because of its controlled nature, which imposes restrictions on the development of this type of usage monitoring application.

The application was installed in 28 sets of Brazilian and Portuguese university students, of which 23 remained in the research, presenting consistent usage data. The absence of five respondents can reside either in the uninstallation of the application (or subsequent abandonment of participation in the research) or in its reinstallation, which generated a new user's record. The difficulty of identifying the cause of this break lies in the anonymous feature of the data. The total valid sample for the research was composed of 12 Portuguese students from the areas of Social Communication and Design and 11 Brazilian university students from the areas of Journalism, Marketing and Public Relations and Public Relations.

The students were recruited directly by the researchers themselves and were informed about how the data would be collected and treated in an absolutely anonymous way. The app was installed by them in their primaryuse mobile phones. When installing the app, participants entered only information about their country of origin and place of study, based on four options offered by the system: Portuguese resident in Portugal;

- Brazilian resident in Portugal;

- Portuguese resident in Brazil;

- Brazilian resident in Brazil.

Data collection took place between December 15, 2017 and January 17, 2018, with a total of 317,938 interactions recorded.

In addition to the make and model of the phone and the date and time of installation of the app, another 12 types of registrations of the participating mobile phones were registered:

1. record of changes in the use of airplane mode;

2. apps installation;

3. apps use;

4. battery consumption level;

5. boot record;

6. use of headphones;

7. recording of photos or videos on the phone;

8. network traffic (in bytes sent and received);

9. connection to the power supply cable (mobile phone charging or discharging);

10. Display on or off;

11. Level of storage available on smartphone;

12. user presence (phone unlock).

Starting from the research hypothesis of this article, from the total of the interactions 
analysis the 64,881 records related to the use of the applications was privileged. This specific category recorded three basic sets of information regarding this usage:

- app name and opening registration (foreground),

- app opening time and

- app time in the foreground through the registration of start-up and end-use in the foreground.

Among these data, and considering the objectives of this work, it was privileged the opening of the applications since mobile consumption is recognized by its fragmented use feature, having less time relevance in the profile of this research. No personal data was collected from the use of each app, such as information on which websites visited or data related to posts or comments made available on social networks.

\section{Results and discussion}

After monitoring the mobile phones of the participants in the study (28 in total and 23 employed), this is the general record of the activities:

TABLE 1 - Movement record from the monitoring of mobile phones.

\begin{tabular}{|c|c|c|}
\hline $\begin{array}{c}\text { MONITORIZATION } \\
\text { RECORD }\end{array}$ & $N$ & $\%$ \\
\hline 1. Screen & 114,218 & 35.9 \\
\hline 2. App usage & 64,881 & 20.4 \\
\hline 3. User present & 46,463 & 14.6 \\
\hline 4. Media added & 26,242 & 8.3 \\
\hline 5. Connection change & 20,416 & 6.4 \\
\hline 6. Headset plug & 15,866 & 5 \\
\hline 7. Heartbeat & 11,664 & 3.7 \\
\hline 8. Power & 6,663 & 2.1 \\
\hline 9. Network usage & 6,305 & 2 \\
\hline
\end{tabular}

\begin{tabular}{lcc}
\hline \multicolumn{1}{c}{$\begin{array}{c}\text { MONITORIZATION } \\
\text { RECORD }\end{array}$} & N & $\%$ \\
\hline 10. Location & 2,571 & 0.8 \\
11. Battery status & 1,492 & 0.5 \\
12. App installed & 807 & 0.3 \\
13. Boot & 245 & 0.1 \\
14. Airplane mode & 58 & 0.02 \\
15. Storage status & 47 & 0.01 \\
Total: & $\mathbf{3 1 7 , 9 3 8}$ & $\mathbf{1 0 0}$ \\
\hline
\end{tabular}

Source: The authors.

We can see that the use of applications represents $20.4 \%$ of registered movements; therefore, a total of $N=64,881$ interactions, the sample we have subsequently worked at the statistical level.

Before proceeding with the report of the main results of this study, it is convenient to clarify several pertinent methodological aspects. The first one consisted in the recoding of the nominal variable (chain) "name of the application", which registered a total of 376 options, in another numerical nominal in which each category was assigned a value or label (from 1 to 376). Subsequently, and from this numerical variable, it was possible to proceed to its recoding in different dummy variables (presence "1" or absence "o" of the element in question), corresponding to the main mobile applications that focused our interest.

In the same way, and taking as a standpoint a total of 8 registered social networks (Facebook, Instagram, Linkedln, Pinterest, Snapchat, Tinder, Tumblr and WhatsApp), their values were computed to form an "Indicator of Interaction with Social Networks" (from now on referred as I2SN), whose range goes from "O" to " 1 ". Following this strategy, an "Indicator of Second Uses" (hereinafter, ISU) was also created, with the same rank, related to pre-existing elements of the appearance of the mobile phone; this is: camera, calculator, recorder, calendar and clock. 
However, and before showing the results of the aggregated indicators, let's analyse the descriptive data related to the different social networks, a topic of undeniable interest in the current media arena:

TABLE 2 - Descriptions of the user's interactions with each of the social networks, and number of users who used it at least once.

\begin{tabular}{lccccc}
\hline SOCIAL NETWORKS & USERS & M & SD & \% & N \\
\hline 1. Instagram & 23 & 0.124 & 0.329 & 12.4 & 6,017 \\
2. WhatsApp & 17 & 0.098 & 0.298 & 9.8 & 6,134 \\
3. Facebook & 23 & 0.095 & 0.293 & 9.5 & 1,187 \\
4. Twitter & 6 & 0.018 & 0.134 & 1.8 & 177 \\
5. Snapchat & 6 & 0.003 & 0.052 & 0.3 & 106 \\
6. Pinterest & 7 & 0.002 & 0.040 & 0.2 & 66 \\
7. Tinder & 5 & 0.001 & 0.032 & 0.1 & 11 \\
8. Tumblr & 1 & 0.0002 & 0.013 & 0.02 & 2 \\
9. Linkedin & 1 & 0.00003 & 0.006 & 0.003 & $\mathbf{2 2 , 0 8 2}$ \\
\hline
\end{tabular}

Source: The authors.

It is attested that the most fashionable social network at present is Instagram, protagonist in more than $12 \%$ of the interactions, followed by WhatsApp and Facebook, which are around 10\% each. If we take their means as a reference, we can affirm that the differences between the 9 social networks are statistically significant $\lambda_{\mathrm{w}}=0.662, F$ $\left.(8,64873)=4146.61, p<0.001, \eta^{2}=0.338\right]$ and fit a "small" effect size (Cohen, 1988). In this sense, and as postulated before, Instagram is the most widespread social network ( $M=0.124, S D=0.329$ ), and it differs significantly from both WhatsApp [t $(64880)=13.64$, $p<0.001, d=0.083]$, and Facebook $[t(64880)=15.86$, $p<0.001, d=0.093$, its most immediate persecutors. However, both differences are considered "small" depending on the size of the effect (COHEN, 1988).

Regarding the correlations that occur between the 4 main social networks (the other 5 were discarded for this analysis because they presence is almost residual), see the following matrix of correlations:
TABLE 3 - Correlations Matrix between the main social networks (Mathew's correlation coefficient)

\begin{tabular}{lcccc}
\hline $\begin{array}{c}\text { SOCIAL } \\
\text { NETWORKS }\end{array}$ & $\mathbf{1}$ & $\mathbf{2}$ & $\mathbf{3}$ & $\mathbf{4}$ \\
\hline 1. Instagram & & & & \\
2. WhatsApp & $-0.124^{\ldots *}$ & & & \\
3. Facebook & $-0.121^{\ldots *}$ & $-0.107^{\ldots *}$ & \\
& & & \\
4. Twitter & $-0.051^{\ldots *}$ & $-0.045^{\ldots *}$ & $-0.044^{\ldots}$ \\
\hline
\end{tabular}

Note: ${ }^{\cdots} p<0.001$. Source: The authors.

Considering the data, it is clear that the highest correlations occur between Instagram and WhatsApp $\left[r_{\phi}(64879)=-0.124, p<0.001\right]$, and Instagram and Facebook $\left[r_{\phi}(64879)=-0.121\right.$, $p<0.001]$. Furthermore, both correlations are 
negative, so the more the interaction with one of them increases, the more the other decreases.

On the other hand, we established two groups of users according to their geographical origin: Portugal ( $n=12$ users) or Brazil ( $n=11$ users); which permitted to establish comparisons in terms of the interactions that ones and the others make with the main social networks. Thus, based on the average of the interactions, see the differences in the following graph:

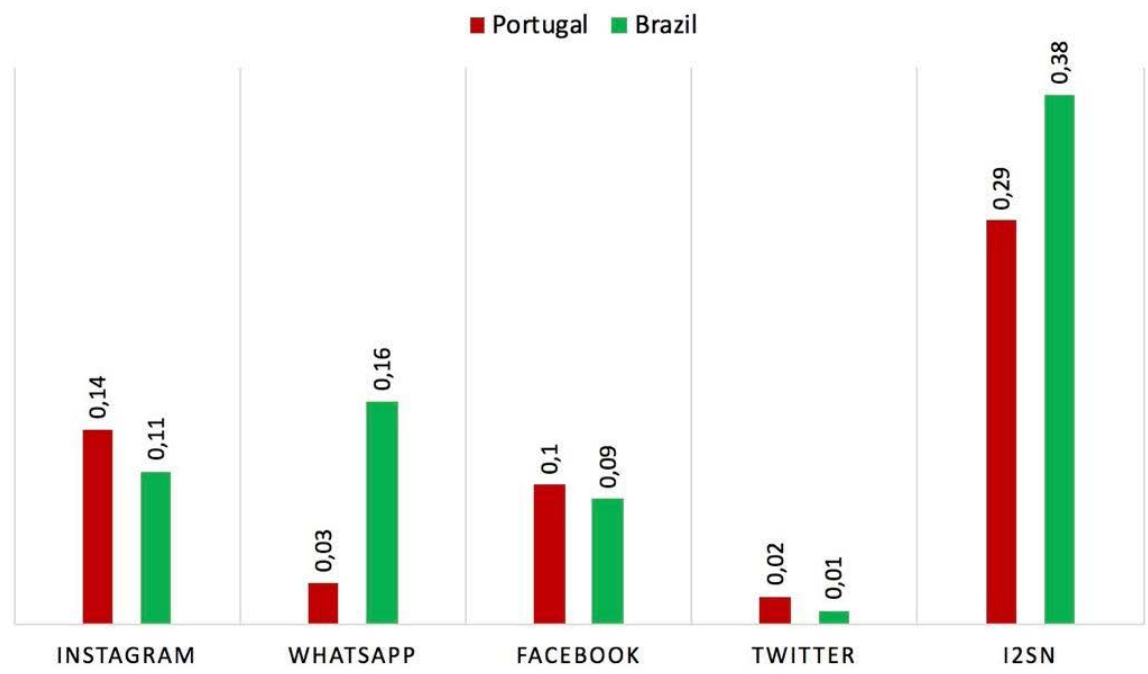

Figure 1 - Portugal vs. Brazil comparison based on the usage of social networks. Source: The authors.

We perceive that the biggest contrasts are generated in relation to Instagram and WhatsApp. The use of Instagram is a more widespread practice among Portuguese users $(M=0.14, S D$ $=0.34)$ when compared to Brazilians $(M=0.11, S D=$ $0.31)$, assuming statistically significant differences [t $(64231)=10.183, p<0.001, d=0.092$ ], although small by the size of the effect. On the other hand, with regard to WhatsApp, the Brazilian users ( $M$ $=0.16, S D=0.36$ ) are the ones that use more it intensively compared to the Portuguese $(M=0.03$, $S D=0.15$ ), giving rise to statistically significant differences $[t$ (64231) $=-58.923, p<0.001, d=$ -0.471 , and of medium size according to its effect. Finally, and at the aggregate level, the I2SN also showed statistically significant differences I $t$ (64231) $=-23.215, p<0.001, d=-0.193]$, although small, between Portuguese $(M=0.29, S D=0.45)$ and Brazilians ( $M=0.38, S D=0.48)$.

In the following table you can see the descriptive statistics corresponding to the main uses conferred to the mobile phone, registered in this study:

TABLE 4 - Percentage, mean and standard deviation of the interactions with each of the mobile applications.

\begin{tabular}{lccccc}
\hline \multicolumn{1}{c}{ APPS } & USERS & $\boldsymbol{M}$ & $\boldsymbol{S D}$ & $\%$ & $\boldsymbol{N}$ \\
\hline 1. I2SN & 23 & 0.341 & 0.473 & 34.1 & 22,082 \\
2. Messages & 23 & 0.084 & 0.277 & 8.4 & 5.453 \\
3. ISU & 23 & 0.042 & 0.201 & 4.2 & 2,765
\end{tabular}




\begin{tabular}{lccccc}
\hline \multicolumn{1}{c}{ APPS } & USERS & $\boldsymbol{M}$ & $\boldsymbol{S D}$ & $\%$ & $\boldsymbol{N}$ \\
\hline 4. Navigation & 22 & 0.031 & 0.176 & 3.1 & 2,066 \\
5. Voice & 20 & 0.027 & 0.165 & 2.7 & 1,811 \\
6. Video & 23 & 0.018 & 0.134 & 1.8 & 1,181 \\
7. Music & 19 & 0.013 & 0.117 & 1.3 & 900 \\
8. E-mail & 19 & 0.011 & 0.106 & 1.1 & $\mathbf{7 4 3}$ \\
9. News & 2 & 0.001 & 0.035 & 0.1 & $\mathbf{7 8}$ \\
\end{tabular}

Source: The authors.

Considering the averages, we can affirm that the variances between the different uses are statistically significant $\left[\lambda_{w}=0.499, F(8,64873)\right.$ $\left.=8146.87, p<0.001, \eta^{2}=0.501\right]$, and adjust to $\mathrm{a}$ "medium" effect size (Cohen, 1988). In this sense, the predominant use is related to social networks through I2SN [M = 0.341, SD = 0.473], which differs significantly from both messages $[t(64880)=$ 109.003, $p<0.001, d=0.663$, and the so-called "second uses" [t $(64880)=139.787, p<0.001, d=$ $0.822]$. Both differences are considered "medium" based on the size of the effect (Cohen, 1988).

As for the correlations that occur between each use, see the data of the following matrix:

TABLE 5 - Matrix of correlations between the uses of the different applications (Mathews correlation coefficient).

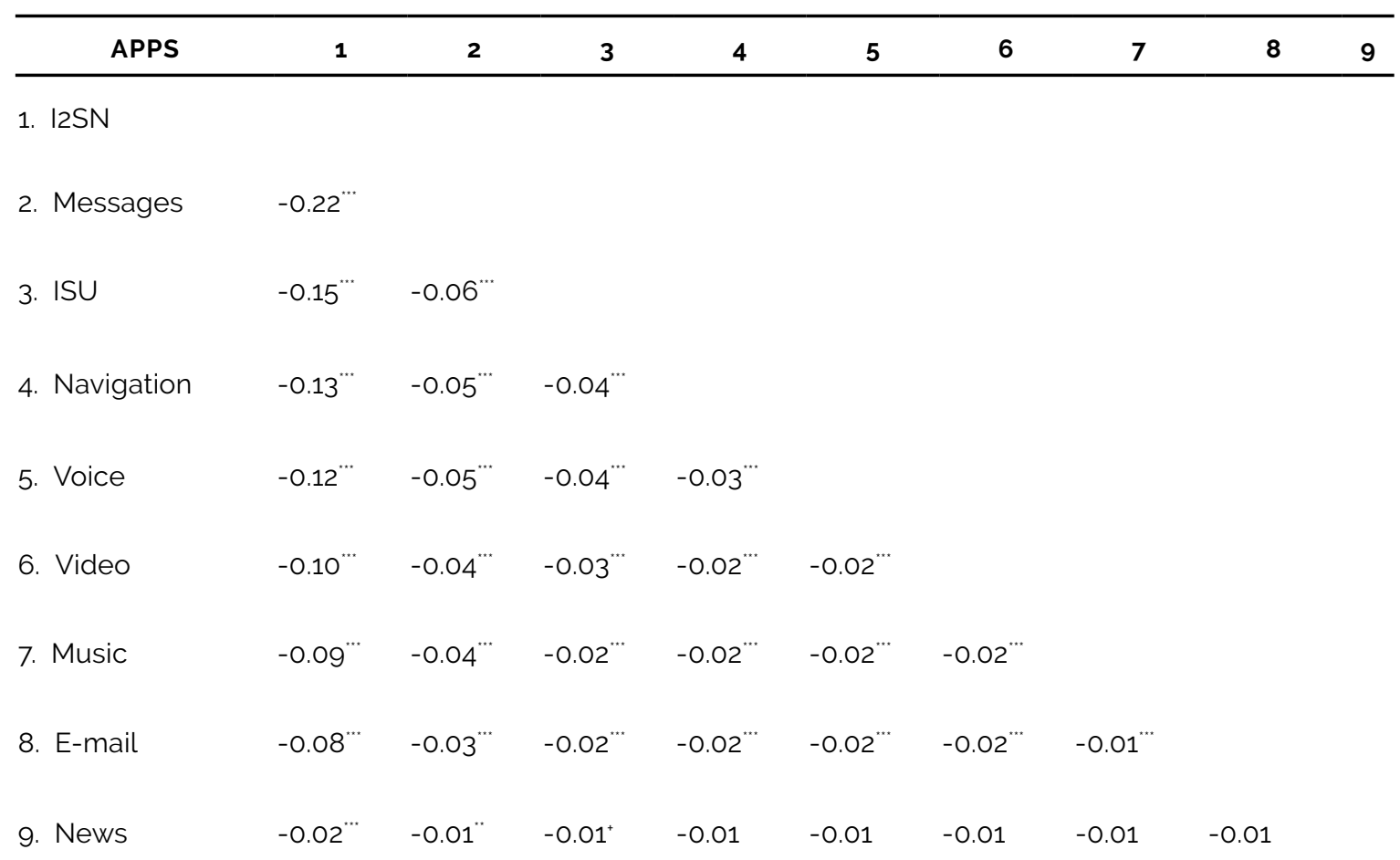

Note: ${ }^{+} p<0.10, " p<0.01, \cdots p<0.001$. Source: The authors. 
From the data, it is noticeable that the highest correlations occur between the I2SN and the messages $\left[r_{\phi}(64879)=-0.22, p<0.001\right]$, and the I2SN and the ISU $\left[r_{\phi}(64879)=-0.15, p<0.001\right]$. Note also that both correlations are negative, so that the more the interaction with one type of application increases, the more the use of the other decreases.

\section{Conclusions}

Although this is a work in progress, at this stage it is safe to say that the data confirms previous studies (FORTUNATI; TAIPALE, 2014) in which smartphones emerge as a platform for exchanging written messages. It is surprising that a device created to allow oral verbal communication has become a platform for verbal written communication and non-verbal communication, such as the emoticons that are increasingly used. Also confirms Bowen and Pistilli (2012) conclusions, because students prefer apps in detriment of the use of the mobile browser.

Among social networks there is a preference among young people for the messaging services offered by these networks and it seems clear that the smartphone is bringing together a set of functions previously assigned to other devices (ISU-second uses).

Looking at what young people do most with smartphones (communicating through social networks and using it as a substitute for other devices) one notices the centrality achieved by these devices in their daily life and the growing importance they have in their life since the smartphone concentrates in a single device of personal use a set of valences previously distributed among other devices. It is anticipated that the emergence of more affordances, coupled with responding to new user needs, will fuel the innovation process that will reinforce the role of mobile phones in society.

Among the social networks most used by these university students are Instagram, followed by Facebook, WhatsApp and, finally, Twitter. The remaining networks have a marginal use. The highest correlations are between Instagram and WhatsApp, but also between Instagram and Facebook, but both are negative, which refers to a scenario of user loyalty to the network commonly used.

This scenario of centrality of the mobile phone, identified in the present study, reinforces the results obtained in previous studies, and also the idea that these devices have become a kind of obligatory clothing among youngsters (CEVALLOS, 2009).

\section{João Canavilhas \\ Doutorado na Universidad de Salamanca (Espanha), tendo apresentado a tese Webnoticia: propuesta de Modelo periodistico para la WWW. Leciona na Universidade da Beira Interior (Covilhã - Portugal), onde atualmente é vice-reitor e pesquisador do Labcom/IFP. É autor ou coautor de vários livros, capítulos de livros e artigos em revistas científicas nacionais e internacionais.}

\section{Correspondência}

Universidade da Beira Interior

R. Marquês de Ávila e Bolama

6201-001 - Covilhã - Portugal

\section{Eduardo Pellanda}

Graduação em Publicidade e Propaganda pela Pontificia Universidade Católica do Rio Grande do Sul (1998), mestrado em Comunicação Social pela Pontificia Universidade Católica do Rio Grande do Sul (2001) e doutorado em Comunicação Social pela Pontificia Universidade Católica do Rio Grande do Sul (2005). Pós-Doutor pelo Massachusetts Institute of Technology (MIT) - Boston - EUA. Atualmente é professor da Pontificia Universidade Católica do Rio Grande do Sul e membro do programa de Pós-Graduação em Comunicação da mesma instituição.

\section{Correspondência}

Pontifícia Universidade Católica do Rio Grande do Sul Avenida Ipiranga 6681 - Partenon 90619-900 - Porto Alegre (RS) - Brasil

\section{Valeriano Piñeiro-Naval}

Graduação em Publicidade e Relações Públicas (Universidade de Vigo, 2008) e Comunicação Audiovisual (Universidade de Salamanca, 2009). Doutor em Comunicação Audiovisual, Revolução Tecnológica e Mudança Cultural pela Universidade de Salamanca (2015) e atualmente é membro da unidade do LabCom da Universidade da Beira Interior (UBI). 


\section{Correspondência}

Universidade da Beira Interior

R. Marquês de Ávila e Bolama

6201-001 - Covilhã - Portugal

\section{Ana Cecília B. Nunes}

Coordenadora acadêmica do IDEAR - Laboratório Interdisciplinar de Empreendedorismo e Inovação da PUCRS e professora dos cursos de graduação de Jornalismo e Publicidade e Propaganda da mesma universidade, lecionando disciplinas sobre empreendedorismo, inovação e comunicação digital. Doutoranda em regime de cotutela pelo Programa de Pós-graduação da Faculdade de Comunicação Social da PUCRS (PPGCOM/PUCRS) e pela Universidade da Beira Interior (UBI - Portugal), pesquisando sobre inovação em mídia, particularmente no jornalismo.

\section{Correspondência}

Pontifícia Universidade Católica do Rio Grande do Sul

Avenida Ipiranga 6681 - Partenon

90619-900 - Porto Alegre (RS) - Brasil

\section{References}

AGUADO, J. M.; MARTÍNEZ, I. J. Sociedad Móvil: tecnología, identidad y Cultura. Madrid: Edit. Biblioteca Nueva, 2008

AHN, J.; JUNG, Y. The common sense of dependence on smartphone: A comparison between digital natives and digital immigrants. New Media \& Society, [S. l.], v. 18, n. 7. p. 1236-1256, 2016. https://doi. org/10.1177/1461444814554902

AKER, J. C.; MBITI, I. M. Mobile phones and economic development in Africa. Journal of Economic Perspectives, Nashville, v. 24, n. 3, p. 207-232, 2010 https://doi.org/10.1257/jep.24.3.207

ANATEL, A. N. d. T. Brasil registra redução de $\mathbf{2 , 8 8 \%}$ no número de acessos em operação na telefonia móvel em 12 meses, 2018. Retrieved from: http:// www.anatel.gov.br/dados/destaque-1/283-brasil-tem-236-2-milhoes-de-linhas-moveis-em-janeiro-de-2018. Access in: 25 nov. 2019. https://doi. org/10.17771/pucrio.acad.8647

AOKI, K.; DOWNES. E.J. An analysis of young people's use of and attitudes toward cell phones. Telematics and Informatitics, [S. L.], v. 20, p. 349-364, 2003. https://doi.org/10.1016/s0736-5853(03)00018-2

BOWEN, K.; PISTILLI, M. D. Student preferences for mobile app usage. Research Bulletin. EDUCAUSE Center for Applied Research, Louisville, 2012. Available from: http://www. educause. edu/ecar. Access in: 25 nov. 2019.
CASTELLS, M.; MAJER, R. V.; GERHARDT, K. B. A sociedade em rede. Lisbon: Fundação Calouste Gulbenkian, 2002.

CEVALLOS, M. del C. Jóvenes y celulares: las razones de su uso y abuso. Ciespal, 2009. Available from: http://www.ciespal.net/ciespal/images/docu/ produccionacademica/Informe\%20celulares.pdf. Access in: 25 nov. 2019.

COHEN, J. Statistical power analysis for the behavioral sciences. 2nd ed. Hillsdale: Lawrence Earlbaum Associates, 1988.

\section{FARAGO, P. iOS and Android adoption explodes} internationally. USA: Flurry,2012.

FISHER, S. America Calling: a social history of the telephone to 1940. Los Angeles: University of California Press, 1992.

FORTUNATI, L.; TAIPALE, S. The advanced use of mobile phones in five European countries. British Journal of Sociology, London, v. 65, p. 317-337, 2014. https://doi.org/10.1111/1468-4446.12075

LANSEN, A. Affective technologies - Emotions and mobile phones. Receiver, v. 11, 2004.

LÉVY, P. O que é o virtual. São Paulo: Editora, 34, 1996

MUISE, D.; PAN, J.; REEVES, B. Content over Format: Modern Device Usage and a Realignment of the News Definition. C+J '17, Evanston, Illinois, US, 2017.

PELLANDA, E. C.; PASE, A. F.; NUNES, A. C. B.; STRECK, M.; SOUZA, D.; FERREIRA, I. M. Comunicação e mobilidade: proposta de procedimento metodológico para o entendimento da audiência mobile através de um estudo de caso do Ubilab/PUCRS. Porto Alegre: PUCRS, 2018. https://doi.org/10.12804/revistas.urosario.edu.co/disertaciones/a.6072

PELLANDA, E. C. Internet móvel: novas relações na cibercultura derivadas da mobilidade na comunicação. PHD Thesis - Pontifical Catholic University of Rio Grande do Sul, PUCRS, Porto Alegre, RS, Brazil, 2005. https://doi.org/10.5783/rirp-9-2015-05-67-88

PRENSKY, M. Digital natives, digital immigrants part 1. On the horizon, [S. l.], v. 9, n. 5, p. 1-6, 2001.

RAINIE, L.; ZICKUHR, K. Americans' views on mobile etiquette. Pew Research Center, v. 26, 2015

STATCOUNTER GLOBAL STATS. Mobile Operating System Market Share Brazil, 2018a. Retrieved from: http://gs.statcounter.com/os-market-share/mobile/brazil/\#monthly-201701-201712. Access in: 25 nov. 2019 .

STATCOUNTER GLOBAL STATS. Mobile Operating System Market Share Portugal, 2018b. Retrieved from: http://gs.statcounter.com/os-market-share/ mobile/portugal/\#monthly-201701-201712. Access in: 25 nov. 2019

SECOM, S. d. C. S. Pesquisa brasileira de mídia 2015: Hábitos de consumo de mídia pela população brasileira. Secom Brasilia, 2014. 
SECOM, S. D. C. S. Pesquisa brasileira de mídia 2016: hábitos de consumo de mídia pela população brasileira. Secom Brasília, 2015.

TURKLE, S. Stop googling. Let's talk. New York Times, v. 27, 2015.

TURKLE, S. Alone together: Why we expect more from technology and less from each other. Hachette: Basic Books, 2017. https://doi.org/10.5613/rzs.41.3.7

WEl, Carolyn Y. Capturing Mobile Phone Usage: Research Methods for Mobile Studies. In: PROFESSIONAL COMMUNICATION CONFERENCE, Seattle, 2007. https://doi.org/10.1109/ipcc.2007.4464062

WELLMAN, B.; TINDALL, D. Reach out and touch some bodies: how social networks connect telephone networks. Progress in Communications Research, [S. l.], v. 13, p. 63-94, 1993. 